\title{
How Does Employee Involvement Stack Up? The Effects of Human Resource Management Policies on Performance in a Retail Firm
}

\author{
Derek C. Jones, Panu Kalmi and Antti Kauhanen'
}

December 13, 2006

\begin{abstract}
By assembling and analyzing new panel data, we investigate the impact of innovative human resource management (HRM) practices on performance for a retail firm. Monthly financial and performance data for 2001-2003, for all (47) units, are combined with information for crucial aspects of HRM environments obtained from employee surveys and multiple case visits. Our rich data include measures of the operating environment, important dimensions of core inputs and output is measured as value added. Augmented production functions, including specifications with both establishment and manager fixed effects, are estimated. We find that when employees have opportunities to participate, receive appropriate information and pertinent rewards, productivity is enhanced. Thus even in settings where employees do simple tasks and employees are relatively low-skilled our findings provide more solid support than many earlier studies for retailing and service firms that novel HRM practices can improve business performance.
\end{abstract}

Keywords: retail trade, productivity, human resource management (HRM), insider econometrics, employee involvement

\footnotetext{
' D.C. Jones: Hamilton College, Clinton NY 13323, e-mail djones@ hamilton.edu; P.Kalmi and A. Kauhanen: Department of Economics, Helsinki School of Economics, and HECER, P.O. BOX 1210, Helsinki 00101, Finland, e-mail panu.kalmi ahse.li, antti.kauhanenahse.fi. Kauhanen is the corresponding author. The authors are grateful to support from the Academy of Finland (Project No. 206027) and The Finnish Work Environment Fund (Grant No. 103313). Jones' work was supported in part by a Foundation for Economic Education Fellowship and NSF SES-0522117 for which he is grateful. Part of the research was carried out when Kalmi was visiting the ILR School at Cornell University and when Kauhanen was visiting SKOPE at the University of Oxford and they are grateful for the respective institutions for their generous support. The paper has benefited from comments on an earlier draft by seminar participants at the NFF annual conference at Aarhus, SKOPE, Oxford, Finnish Society for Economic Research XXVII Annual Meeting, Cornell University, Rutgers University, and by Jed DeVaro, Tor Eriksson, Kevin Hallock, Pekka Ilmakunnas, Jeffrey Pliskin, Matti Pohjola and Petri Rouvinen. The authors are extremely grateful to a number of individuals working for the case firm for interviews, comments and access to the data. The data used in this study are proprietary and were obtained only by signing a confidentiality agreement. Hence the authors are unable to release these data.
} 


\title{
How Does Employee Involvement Stack Up? The Effects of Human Resource Management Policies on Performance in a Retail Firm
}

\begin{abstract}
By assembling and analyzing new panel data, we investigate the impact of innovative human resource management (HRM) practices on performance for a retail firm. Monthly financial and performance data for 2001-2003, for all (47) units, are combined with information for crucial aspects of HRM environments obtained from employee surveys and multiple case visits. Our rich data include measures of the operating environment, important dimensions of core inputs and output is measured as value added. Augmented production functions, including specifications with both establishment and manager fixed effects, are estimated. We find that when employees have opportunities to participate, receive appropriate information and pertinent rewards, productivity is enhanced. Thus even in settings where employees do simple tasks and employees are relatively low-skilled our findings provide more solid support than many earlier studies for retailing and service firms that novel HRM practices can improve business performance.
\end{abstract}

Keywords: retail trade, productivity, human resource management (HRM), insider econometrics, employee involvement 


\section{Introduction}

In this study we assemble a unique panel data set from a large Finnish retail firm and use it to investigate the impact of innovative human resource management practices (hereafter, HRM) on firm performance. In many countries including the U.S. and Japan (e.g. Osterman, 2000; Blasi and Kruse, 2006; Kato, 2006) recent years have witnessed extensive reforms in work organization. Unsurprisingly the literature that examines the links between HRM and business performance has also grown rapidly as scholars from different fields in the broad area of industrial relations have applied varying approaches to explore new types of evidence and research questions. One prominent approach is "insider econometrics" (Ichniowski and Shaw, 2003) or econometric case studies (Jones and Kato, 2004). In such studies the natural focus is on the effect of a single HRM practice on productivity and examples of recent studies using this approach include Lazear (2000) and Hamilton et al. (2003). A crucial advantage of this method is that researchers are able to acquire a much more thorough understanding of the particular production process and therefore are able to estimate the production function and test associated hypotheses in a much more reliable way than are researchers who rely only on survey data (Ichiniowski and Shaw, 2003). Moreover, since the units being compared are often fairly homogenous in many respects, the confidence on the reliability of the estimated coefficients of primary interest is greatly increased.

Insider econometric studies of firms outside of manufacturing are very scarce and the bulk of empirical literature of any kind in the broader field of HRM-performance has concentrated on manufacturing companies (e.g. Ichniowski et al., 1997; Appelbaum et al., 2000). While there are some important exceptions of research on service sector firms, especially Batt's work on telecommunications industry (e.g. Batt, 1999; 2002) and Bartel's (2004) study of a Canadian bank, studies on the HRM-performance link in the retail sector are rare. An important contribution of the paper stems from this fact that research on service sector firms 
is quite sparse; indeed ours may be the first econometric case study for a retailing firm.' The study of firms in the service sector is important since the nature and scope of the gains from the use of innovative HRM practices and the most important channels of HRM may not be universal but instead may be expected to vary by sector or by other contingencies (Delery and Doty, 1996; Baron and Kreps, 1999; Appelbaum et al., 2000).

Thus, since retail trade is characterized by low pay, a high proportion of part-time employees, and a high proportion of female employees, it has been suggested that the HRM environment in the retail sector would be rather traditional (Kauhanen 2006). Similarly, Appelbaum and Batt (1994) have argued that services often lag behind manufacturing in the introduction of workplace innovations, such as total quality management or autonomous teams. However, globalization and regulatory changes that have increased competition have compelled service providers to consider means for improving productivity by the application of advanced HRM practices.

Another contribution of the study is that we extend the geographical range of empirical studies-- to date most empirical work in this field has focused on firms in North America and it is important to see if findings derived from studies of cases elsewhere carry over to other countries. Ours is the first such study of a firm in Finland. ${ }^{2}$ After Finland joined the European Union in 1995, many businesses were exposed to a much more competitive environment. This has posed challenges to the Finnish retail trade sector where productivity has been relatively low in international comparisons (Mankinen et al., 2002; Jalava, 2005.) Hence, knowledge about the potential impact of HRM on performance in Finnish service firms is especially pertinent for Finnish companies, as well as service sector firms elsewhere that face enhanced competition in an increasingly integrated world.

By undertaking visits to selected branches as well as the firm's operational headquarters, we have collected most unusual data from the case. These include monthly financial and 
performance data for the period 2001-2003 for all branches. These data are combined with information for crucial aspects of HR environments that are obtained from annual employee surveys that capture key dimensions of employees' perceptions of HRM practices and are integrated with information on managerial turnover and other controls that capture differences in the retailing environment. By estimating augmented production functions and using panel data methods (that include both establishment and manager fixed effects as well as month and year dummies) we provide what we believe are some of the most reliable findings that are available on the HRM-performance link for a service sector firm. Our main results are robust to using annual (rather then monthly) performance measures. In addition, our estimating methods are supported by exogeneity tests.

\section{Theoretical Framework and Empirical Literature}

Since ours is not a theoretical contribution, here we continue by merely highlighting some key themes in that literature. We endeavor to focus on those theoretical aspects that are most pertinent for our particular case, a retailing firm with a specific set of HRM policies.

The idea of employee involvement as part of HRM strategy is not new. As early as the 1930 s the human relations school argued for the benefits of employee involvement programs. ${ }^{3}$ More recently, a useful framework for analyzing the effects of employee involvement has been developed by Appelbaum et al. (2000). Their premise is that employees may possess valuable information on the production process (here the service process) that management may not have. The firm would like its employees to use this knowledge to benefit the organization. In order to elicit higher discretionary effort from employees, three conditions have to be met. First, employees need to be able to participate in substantive decisions. Second, employees need to have appropriate skills and, third, employees need appropriate incentives. ${ }^{4}$ 
This framework implies that employees cannot supply discretionary effort if they do not have either the channels through which to participate in substantive decisions or the skills required to make it worthwhile or sufficient information. In addition this approach implies that employees are not willing to supply discretionary effort if they do not have the appropriate incentives to do so and also emphasizes the need for a coherent system of HRM practices. The benefits of coherent practices are not unique to this framework, but there appears to be consensus that economic payoff of HRM practices is likely to be greater when packages of measures exist. For example, Ichniowski et al. (1997) argue that there are powerful complementarities when sets of HRM practices coexist. However, if inconsistent or defective sets of HRM practices are implemented, the literature suggests the possibility of negative or negligible effects on business performance. For example, Ben-Ner and Jones (1995) point out that employee involvement alone may not lead to enhanced business performance, especially in the absence of increasing return rights.

In examining particular components of the HRM environment, the opportunity to participate in decisions may have an impact on productivity through multiple channels. First, it may affect employee motivation to put forth effort. Benabou and Tirole (2003, Section 3) show that empowering an employee to carry out some task demonstrates the supervisor's trust in the agent's ability or motivation to carry out the task, which in turn leads to a higher level of effort in equilibrium. Second, participation may develop employee skills. Batt (2002) argues that opportunities to participate in job design enable employees to learn about the content of their work and also to make productive suggestions. Appelbaum et al. (2000) find that participation also increases the intrinsic rewards from work. The next section discusses in more detail how participation may affect productivity in our case.

Preuss (2003) argues that the opportunities to participate and employee skills can lead to higher performance only when employees receive sufficient information concerning their 
work tasks. In our empirical analysis, we also consider information regarding the performance of the department as an important part of the overall HRM environment.

In circumstances where the role of the monetary incentives is limited, as is true in this retail case, the role of managerial recognition may be pronounced. For instance, Benabou and Tirole (2003) argue that managerial recognition of work that is well done may increase agents' intrinsic motivation to put forth effort in the future.

When the employees' tasks are interdependent, it becomes important that each employee within the department shares the same goals. Otherwise an individual employee may inflict disproportionate damage to the departmental performance by withholding effort and performing actions that are not consistent with what others are doing.

Some authors have stressed the role of the production technology in determining the effectiveness of employee involvement (e.g. Baron and Kreps, 1999). According to Ben-Ner et al. (1999), in situations where task uncertainty, task interdependence and task complexity are relatively low, the pay-offs to innovative HRM practices are relatively low. By and large they argue that retailing firms are expected to provide good examples of this characterization. Similarly, Banker et al. (1996) stress the role of managerial control in situations where task complexity is low and contact with the customer infrequent. In contrast, in situations where salespeople are frequently in contact with the customers, employee motivation, interpersonal skills and product knowledge become important, and HRM policies should be designed to facilitate employee motivation and skill development (see also Batt, 1999; Bartel, 2004).

The effects of HRM practices on performance need not necessarily be positive, even if the practices were introduced in a coherent manner. For example, meetings, whether on an individual or a collective basis, may also take a lot of time away from other activities. Furthermore, HRM practices may also be ineffective or even counterproductive in settings where employees are given expectations about increased discretion, but the expectations are 
not fulfilled (e.g. Heller et al., 1998). Similarly measures designed to improve skills may be poorly implemented or may not succeed if the information on the nature and purpose of a new program is communicated poorly to affected employees.

Turning to the empirical evidence on the impact of HRM practices on productivity in the service sector, as already noted, this is quite limited. Bartel (2004) found that among the branches of a large bank, employee perceptions on performance feedback and recognition systems had a significant and positive impact on the growth of sales of loans. Batt (2002) used a nationally representative sample of call centers and found that greater use of highinvolvement practices was associated with lower quit rates and higher sales growth. Studying a large regional telecommunications company, Batt (1999) finds that the adoption of selfmanaged teams leads to sustained productivity improvements. For the specific case of retailing, Banker et al. (1996) find positive evidence on the effects of incentive pay with retailers operating in upscale markets, but not with those serving the mass market. And in a study of 50 retail cooperatives Jones (1987) found that worker representation on the board of directors and participation in enterprise results were statistically significantly associated with better business performance. ${ }^{5}$

In sum, it appears that the empirical record for the service sector, including retailing, is suggestive of a HR-performance link. However, existing empirical work also draws attention to the difficulties involved in empirical work in this area. For example, there is no general agreement as to what constitutes the preferred set of HRM practices or how the potential gains might be expected to be shared between different parties. Most studies illustrate the difficulties in moving from theory to appropriate empirical specifications, and of the potential sensitivity of findings to, for example, the use of differing scales to capture variation in HR environments. ${ }^{6}$ Also, the measures of productivity are not always ideal - for instance, it is common to use sales rather than value added as a measure of productivity. Hence it is clear 
that empirical analysis in this area is still in its infancy and that more reliable work is needed before these preliminary conclusions can be accepted.

\section{Description of the Finnish context and the Case}

Since the institutional context within which Finnish firms operate is unfamiliar to many, before describing our case we continue by briefly highlighting important features of that environment. As with relatively low-skilled workers throughout the service sector in Finland, ${ }^{7}$ basic terms and conditions of employment are determined by a national collective agreement, in this case for the retail sector. Importantly this agreement provides that employees receive at least the fixed hourly wage that is stipulated in the national agreement of the sector. As retail trade represents an industry where employees have limited bargaining power at the firm level, often there is no wage drift and employees receive only the nationally agreed minimum wage for the sector; this is largely the situation in our case. In 2000 union density in the retail trade sector was $56 \%$, while the gross national average was around $75 \%$ (Böckerman and Uusitalo, 2006). However in Finland agreements are generally binding, which means that the wages of non-union workers are also determined by union agreements. Finally, it is important to note that employers cannot dismiss employees at will. In Finland, mass lay-offs are possible only when employers can demonstrate an economic or technological reason, but even this procedure involves extensive negotiations with employee representatives. Individual lay-offs are possible only in the case of gross misconduct, such as theft. Thus even retail employees enjoy considerable job security.

Our case is a Finnish firm in the non-food retailing sector. It has 47 retail outlets around Finland, making it one of the largest retail firms in Finland. Each outlet sells similar items, although there is variation in the number of items sold, since the outlets are of different size ranging from floor space of $542 \mathrm{~m}^{2}$ to $3697 \mathrm{~m}^{2}$. Smaller establishments carry a product assortment that is a subset of the product mix offered by larger stores. Each outlet is divided 
into five departments: cosmetics, clothing, shoes, electronics and home appliances, and sports. The retailer is neither a discount retailer nor can it be considered as a specialized or upscale retailer. Its strategy is to sell rather standard products to a wide range of customers with all items in stock on display, and self-service is the main form of service in many departments. For the bulk of employees the main tasks are to receive goods, shelve items, and maintain the appearance of their department. In departments such as electronics and sports, it appears that customers are apt to call on the expertise of sales clerks more often than in other departments such as clothing.

To help to sharpen the hypotheses that we will derive from the preceding conceptual discussion and also inform our statistical analysis, we endeavored to enrich our understanding of the institutional realities at the case. To this end we read various materials that the company provided such as the HR handbook. We have also spent considerable time on field trips including multiple visits to two (of the 47) outlets of this company in different areas of Finland; during each of these visits we interviewed the store manager and four employees. We have also made repeated visits to the firm headquarters where we have had extensive discussions with senior personnel. Many of these personnel had made frequent and recent visits to branch stores and thus had intimate knowledge of these branches.

All the units share a similar formal set of HRM policies. These are described in the company's HRM handbook and include an emphasis on training and skill formation, policies concerning meetings between employees and supervisors and annual development discussions. For the most part when reading this handbook one gets the sense that the firm is quite traditional and that relatively few novel HRM practices are present. However, as is the case in the bank examined by Bartel (2004), store managers and department supervisors have discretion in implementation of the HRM practices. As was confirmed by our visits and 
discussions, what this means in practice, is that substantial variation in HRM environments exists within the case.

Our investigations showed that work is organized in team-like units, the departments. Employees within sales departments behave team-like in the sense that each employee is trained to perform multiple tasks within the department, and one salesperson may substitute for another when needed. However, no formal authority is transferred to teams. At the same time, sales personnel have individual responsibility for certain products including having discretion in the display of products. In such ways employees participate in substantive decisions. Employee skills are acquired through in-house or on-the-job training and the company operates its own training institute. Supervisors may enroll employees in a course that the institute offers, or the employees may themselves suggest courses. These skills help the employees in managing their products and thus in participation in decision making. Furthermore, as a by-product of participation in training programs, team spirit and commitment to shared goals is fostered.

The HRM handbook requires that supervisors and employees should have regular meetings (typically weekly or bi-weekly), where issues related to the day to day operations of the departments are discussed. This is an important channel of information from the supervisors to employees and vice versa. Employees get information that helps them to plan their own work ahead. Employees also receive group feedback at these meetings about their collective performance. At the individual level, there is also a policy of annual development discussions. The items discussed in development talks usually relate to how employees have performed in their jobs, how they could further improve, what training needs they have, and what kind of future prospects they have within the store. Arguably these discussions provide an important channel for non-monetary rewards in the form of managerial recognition. An important aspect of these talks is discussion of possible promotions. Supervisors are typically 
chosen from the ranks of the salespersons, and promotion to supervisor would increase both pay and status considerably. Thus development talks are both an important element in overall HRM policies and also of substantial interest to employees. However, in practice there is considerable variation in the implementation of this policy. For instance, in one store we visited only $35 \%$ of employees had participated in development talks in 2003. But in another store, the corresponding percentage was $93 \%$.

Finally, only managerial employees are entitled to incentive pay and shop-floor employees get the nationally negotiated fixed wage. ${ }^{8}$ Therefore, motivating shop-floor employees to put forth discretionary effort must rely mainly on intrinsic motivation, managerial recognition and promotions.

In our store visits, we asked managers and employees how company salespersons can influence store productivity. One of two broad categories of reasons ${ }^{9}$ frequently mentioned by both groups was shelf-management, item display, and the overall appearance of the store. During the study period, employees within sales departments had a lot of discretion concerning item display. In turn this influences the lay-out of the store, which potentially has a large impact on sales. Furthermore, the overall cleanliness and orderliness of the store affects the ability of customers to achieve their objectives in the store (Bitner 1992). To give a concrete example, if items are not shelved in their proper places in the clothing department, customers may be unable to find what they are looking for. Since employees are responsible for given products, their motivation and skills in organizing and managing products efficiently affects the store's productivity. Formal models of shelf management are complex and if market conditions are rapidly changing the value of these kinds of models is diminished (see e.g. Borin and Farris 1995). This is an additional argument that benefits flow from employee involvement in shelf management decisions, especially if information systems are not utilized extensively as is the case in this firm during the time period under study. 
The other set of reasons concerns interaction with customers. In this chain, employees do not usually initiate such contacts. However, when employees are in the store and engaged in other activities (e.g. shelving), often they are approached by customers who are looking for specific products or who want more product information. In such situations, employee reactions have an important bearing on customer satisfaction. If an employee behaves in an unfriendly manner, customer interest may be easily lost. Similarly, employee knowledge (whether the employee actually can respond to the customer questions) potentially has an important impact on customers and thus ultimately on store sales. Bell and Menguc (2002, 140-141) highlight the role of job autonomy, empowerment, and information on customeroriented behavior. They also show that increased customer-orientation leads to increased customer perceptions of service quality.

Based on the preceding discussion we believe that our case is a good one in which to test several hypotheses derived from the literature on the impact of novel HRM practices and performance. These include hypotheses derived from the framework proposed by Appelbaum et al. (2000) who stress the complementary natures of skill, employee involvement and employee motivation in helping to account for differences in business performance. Our case has some individual practices and policies that are non-traditional such as those designed to encourage employee involvement. Since the implementation of these practices varies widely across establishments, we can investigate hypotheses concerning the impact on business performance of these individual elements. In addition, since there are large differences in the overall HR environment across branches, we can test hypotheses concerning the impact of different HR environments on business performance.

Furthermore, from our field-work and interviews we conclude that, typically, interactions between customers and employees are very brief and not very personalized. Hence we would expect that product knowledge would be a more important form of firm-specific human 
capital than is personalized knowledge of customers, although general knowledge about customer preference is certainly very valuable. In other words, the size and strength of the link between those HR policies and practices that promote knowledge and business performance may not be as strong as would otherwise be the case. Also, since shop-floor employees receive a fixed wage, employee motivation must flow from intrinsic rather then extrinsic rewards. In sum, we expect that store productivity depends, among other things, on employee motivation and knowledge, that both of these parameters can be influenced by HRM practices and that this will be so in the more successful outlets in our case.

At the same time our fieldtrips and discussions with managers revealed that there are also a number of crucial differences in the environments that different stores face. For example, the local labor markets facing individual outlets are rather different. In buoyant economic areas such as the Helsinki area, employee turnover is a significant problem for the company, while in more rural areas, which typically have high unemployment, usually employees are more attached to the employer. Although the company has the same formal set of HRM policies throughout its outlets, differences in local labor markets may require different applications of informal HRM practices. In our empirical work, to control for differences in local labor markets and the consequences for output, we will include controls such as tenure and the share of full time workers. It is also clear that different outlets confront other sharp environmental differences, notably differences in competitive pressures. Again in our empirical work we will include controls that attempt to capture such disparities.

\section{The Data and Descriptive Statistics}

The data cover all 47 establishments in the case firm that were operating during 20012003. Of these 47 establishments, 37 are observed for the whole period, while the remaining ten started operations between March 2001 and February 2003. No establishments closed during 2001-2003. Our data consists of 36 monthly observations (2001:1 to 2003:12). Since 
we do not know the number of days a new store operated during the first month (a store could be opened at the end of month), and the first month may be special in other ways as well, we treated observations for the first month of operations as missing for all new establishments. Another way we cleaned the data was to exclude 11 observations which preliminary analysis identified as influential or outliers. ${ }^{10}$

The definition of productivity in the retail sector has been subject to much debate (see, e.g. Reardon et al., 1996). However, value added has been widely accepted as the theoretically preferred measure of retail productivity and fortunately we are able to use such a measure as the dependent variable. Essentially this is defined as net sales minus purchases. ${ }^{11}$ The core input measures we use are quite traditional, namely hours worked and floor space area. Both of these measures have been used in prior studies (e.g., Reardon et al., 1996, 447.)

To capture key facets of the HR environment we use six HRM variables all of which come from a personnel survey that is administered annually by an independent consulting firm. ${ }^{12}$ We received the data directly from the case firm. The survey respondents are the sales clerks at the departments, who are mainly permanently employed but who may work either part-time of full-time. As such respondents correspond to the definition of "core" employees as defined by Osterman (1994). The average response rate is around $60 \%$.

One key practice for which we have data concerns development talks, which are supposedly held annually and usually in the spring. Our measure "Development talks" is the share of employees who have gone through development talks (with either their supervisor or their manager). There is substantial variation in this measure: while in most stores in most years all or almost all respondents indicate that they have had a development talk with their superior, in about a third of stores there are years when fewer than $50 \%$ of respondents had had these talks. These numbers were particularly low in the last year of the sample (2003), perhaps suggesting that commitment to this practice tends to wear out over time. 
In a similar vein to Bartel (2004) the other five HR measures we use are employee perceptions of different HR practices. For these variables each observation corresponds to the relative frequency of a response. As with the measure of development talks, the available data indicate much dispersion in these measures across establishments. The first perceptual measure attempts to capture the opportunity to participate in substantive decisions, which theory suggests potentially is an important driver of business performance. "Participation on the job" is measured by the mean of the answers to the statement "I can participate in planning and development of my work" and is measured on a five point Likert-scale ranging from "disagree strongly" to "completely agree". Other variables are measured similarly. Theory also suggests that effective decision making participation requires not only appropriate channels but also adequate and appropriate information. "Information sharing" is the mean of the answers to the statement "I get enough information that is needed to manage in my job".

Earlier it was also argued that information concerning the performance of the group is important for employees" effort decisions. This is captured by the measure "Performance feedback" which measures managerial attention to performance, and is the mean of answers to the statement "Our department has adequate performance measurement systems". Our theoretical framework also suggests that managerial recognition and confidence in management is an important incentive for the employees to put forth discretionary effort. To capture this aspect of the HRM environment "Acknowledgement" is defined as "I get acknowledgement from my supervisor when I perform well in my job." Finally "Shared goals" is defined as "We try to reach together with my supervisor the goals that have been set". All perceptual variables exhibit much variation, typically from around 2.5 to 4.5 , the mean being around 4 . To assess how much the HRM measures vary over time for given establishments we calculated the share of within variance of the total variance for the 39 
establishments observed in all of the three years ${ }^{13}$. The shares range from $24 \%$ for performance feedback to $52 \%$ for the development talks. This means that there are considerable changes over time in the HRM measures for given establishments. Furthermore, we tried to assess how much of the changes in the HRM measures can be attributed to the survey response rates. To do this we calculated within variances of the HRM measures for each establishment. We then regressed the within variance of each HRM variable on the average response rate. We find no evidence that the average response rate would have an impact on the within variance of the HRM measures. In other words, there is no evidence that establishments with high response rates would have less variability in the HRM measures over time.

Also we wish to capture differences in overall HR environments across establishments. Reflecting the absence of a standard approach in the literature, we will pursue two methods. One way to do this, as in Bartel (2004) and Cappelli and Neumark (2001), is by introducing all elements simultaneously into regression models. However such an approach is likely to be characterized by high correlation between the perceptual measures, and thus a problem for precise estimation of these parameters is created. (In fact the simple correlation coefficients for our 5 perceptual measures range from 0.50 to 0.69 ). The problem of collinearity of the HRM variables has been noted in many studies. For example, in the seminal paper of Ichniowski et al. (1997), they argue that the collinearity of workplace innovations means that they cannot be entered together in regression models. Furthermore, they maintain that estimation of a full set of interaction variables is also impractical and that such variables may also suffer from collinearity. To get around these problems they identify bundles of practices inspecting the distributions of the variables and by using scaling algorithms. Then they create dummy variables depicting different combinations of practices. 
Another response to the problem of collinearity is found in influential studies including Huselid and Becker (1996), MacDuffie (1995) and Huselid (1995), who have used scales, or various summary measures, to describe the HRM environment. ${ }^{14}$ We will build on this line of work and also create a scale which we use in our regression analysis.

Since establishments operate in different parts of the country, there are large differences in operating environments - for example, stores in the capital region have quite different markets when compared to those operating in rural areas. We control for these differences by using a wide range of variables depicting the operating environment. Important characteristics of the environment include population density, net income, net migration, home ownership, the share of the highly educated, the number of establishments operating in retailing per capita, and the average turnover of establishments operating in retailing. These environmental variables are measured at the municipality level and the environmental data (obtained from Statistics Finland) reveal considerable variation in these environmental variables (Table 1.$)^{15}$ Much previous work also indicates that the characteristics of personnel may also affect productivity (see, e.g., Hellerstein and Neumark, 1999; Ilmakunnas et al., 2004). Fortunately, and most unusually, our data enable us to control for many crucial personnel features including the share of male employees, the shares of permanent part time, permanent full time, and temporary employees, and average tenure. ${ }^{16}$ From Table 1 we see that the work force is predominantly female, and that there are a lot of part-timers. It is also apparent that around $70 \%$ of employees have a permanent work contract, meaning that the majority of employees enjoy considerable job security. However, the personnel figures are for all the employees, including personnel at the cash registers. For this reason the figures probably over-estimate the share of part-timers and underestimate the share of permanent employees in the average establishment. Average tenure is 6.7 years and thus quite high. This implies that, on average, employees have had considerable time for on-the-job learning. 
Finally, managerial quality may be expected to affect to affect business performance and yet managerial turnover is unlikely to be time invariant. In fact, of the 47 establishments in our case, 18 experience a change in management. During the period of study, twelve units change their manager once, four do so twice, and the remaining two have three changes. Fortunately, our data enable us to control for managerial turnover across retail units by including monthly manager dummies in our empirical estimates.

\section{[TABLE 1]}

\section{Empirical Strategy and Findings}

In order to use all of the available data, in particular monthly observations on performance, our basic empirical strategy is to estimate production functions. After discussing issues relating to that method we present our findings. To check on the robustness of our key findings, we also report findings from additional empirical work including exercises relating to questions of exogeneity and possible timing issues related to the nature of our data.

The starting point of the analysis is the following augmented Cobb-Douglas ${ }^{17}$ production function

$$
Y_{i m y}=A_{i m y} S_{i y}{ }^{\alpha}\left(E L_{i m y}\right)^{\beta}
$$

Where $Y_{i m y}$ measures production of the unit $i$ at time month $m$ and year $y, A_{i m y}$ represents productivity shocks, $S_{l y}$ is the floor space, and $E L_{i m y}$ is effective labor. The level of effective labor depends on the HRM policies and the composition of the workforce, and we write it as

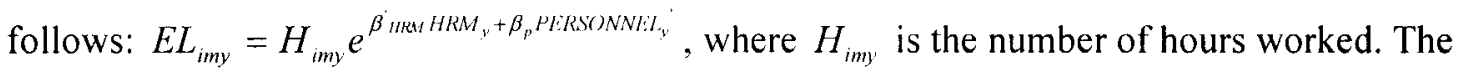
productivity shock can be decomposed into a permanent effect, time effects, and other shocks which vary over time and over establishments. Since the plant manager may have an effect on productivity, we also include management dummies in the productivity shock. We specify the

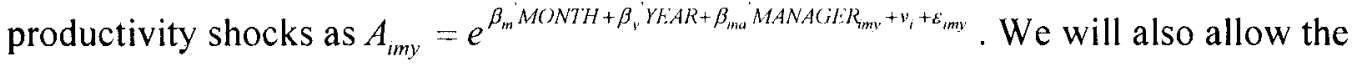


environmental variables to enter the equation, possibly through $\varepsilon_{m y}$. Taking logs of the augmented production function we get

$$
\begin{aligned}
& y_{i m y}=\beta h_{i m y}+\alpha s_{i y}+\beta \cdot \beta^{\prime}{ }_{H R M} H R M_{i y}+\beta \cdot \beta_{p}^{\prime} P_{E R S O N N E L_{i y}} \\
& +\beta_{e} E^{2} \text { VIRONMENT } T_{i y}+\beta_{m a} M A N A G E R_{i m y}+\beta_{m}{ }^{\prime} M O N T H+\beta_{y}^{\prime} Y E A R+v_{i}+\varepsilon_{i m y}
\end{aligned}
$$

where $y_{i m y}$ is the logarithm of value added in establishment $i$ at month $m$, year $y ; h_{i m y}$ is the $\log$ of hours worked, $s_{i y}$ is the $\log$ of floor area; $H R M_{i y}$ is a vector describing the human resource management environment measured annually; $P E R S O N N E L_{i y}$ is a vector describing the composition of work force, ENVIRONMENT $T_{y y}$ is a vector measuring the operating environment of the establishment, $M A N A G E R_{l m y}$ is a vector of manager dummies, MONTH is a vector month dummies capturing seasonal effects, YEAR is a vector of year dummies capturing the effects common to all establishments in a given year, $v$, is the establishment level unobservable component, and $\varepsilon_{i m y}$ is an error term.

Several issues arise in the estimation of the preceding equation. One matter is how to handle the establishment level unobservable component when it is likely that establishment level unobserved factors may affect the choices regarding HRM, even though we have a large set of controls. We allow the explanatory variables to be correlated with $v_{i}$, the establishment specific error term and use establishment fixed effects to control for time invariant establishment characteristics.

A second issue concerns the calculation of standard errors where the need to adjust the standard errors for serial correlation and heteroscedasticity in fixed effects models recently has been emphasized. ${ }^{18}$ Although estimators which take into account these features of the error term have been around at least since the work of Arellano (1987), until recently they have not been widely used. ${ }^{19}$ Fortunately research by Bertrand et al. (2004) and Kezdi (2004) shows that these estimators also perform well in small samples. Furthermore, Kezdi (2004) 
shows that the number of cross section units is the important one, and not the ratio of $\mathrm{N}$ and T. In other words, for these estimators to perform well in small samples, it is not needed that the cross section dimension is large relative to the time dimension. Thus, we can be confident that using an asymptotic approximation is a reasonable procedure.

A third issue is the high correlation of the variables in the HRM vector. As discussed earlier, to respond to this matter we will pursue two strategies. First we will follow one set of influential literature (e.g. Cappelli and Neumark, 2001) and estimate all elements in the HRM vector simultaneously in regression models. Then we will conduct an $\mathrm{F}$ test on the joint significance of the vector of HRM variables. As is the usual practice in the literature (e.g. Bartel, 2004) we will include the mean values of these variables in our regressions. ${ }^{20}$ Second, by using principal component analysis, we create a summary measure of the HRM practices. In constructing an additional scale for the HRM variables we exclude development talks, since the first principal component puts least weight on this variable. ${ }^{21}$ The resulting scale has five components and Cronbach's alpha of $0.88 .{ }^{22}$ Thus this variable is a measure of the overall HRM environment.

Having decided on the appropriate specifications, the next issue that arises is how we will interpret the results. Since we are conditioning on the establishment effect, the interpretation of the parameters comes from the conditional expectation of $y_{i m y}$ on the explanatory variables and the establishment level unobservable component $v_{i}$. The parameters can be given a causal interpretation if the explanatory variables are strictly exogenous, that is, uncorrelated with past, present and future error terms $\varepsilon_{i m y}$. If the HRM variables are correlated with only the time-invariant part of the error term $\left(v_{i}\right)$, then their coefficients can be interpreted as causal. To address these issues we will perform tests of the strict exogeneity assumption. In the fixed effect estimation we use, this leads to our including forward values of the HRM variables as additional covariates. If these variables are found to be significant in the equation, the 
assumption of strict exogeneity will not hold (see, e.g. Wooldridge (2002), 284-285).

Intuitively, the forward values of the HRM variables can only be significant if there is feedback from the error term at time $t$ to the HRM variables at time $t+1$. The results of these tests are discussed along with the estimation results.

While we expect that our preferred estimates will be our fixed effects specifications, first we report OLS estimates. These may be informative since they also exploit the cross sectional variation in the data, whereas the fixed effects models use only variation within establishments. The results are reported in Table 3. The first column gives the baseline specification without any HRM variables. To test hypotheses concerning the sign and significance of individual HR practices, the next six columns enter the seven HRM variables one at a time. In the last column, we report estimates that includes all six HRM measures. By first entering the variables one at a time and then together as a set, we are following the usual practice in the literature as, for example, in Cappelli and Neumark (2001) and Bartel (2004). [TABLE 2]

From Table 2 it is seen that both of the core inputs, hours and floor space, are found to be statistically significant at customary levels and that the coefficients are of expected magnitude. Turning to the composition of the workforce, surprisingly we find that establishments with a higher share of full time workers are less productive (and relative to the omitted category, the share of temporary workers.) At the same time, establishments with higher average tenure are found be more productive so these results may reflect multicollinearity between these two variables. The gender composition of the establishment is not found to be a significant predictor of productivity. Similarly, and perhaps surprisingly, the operating environment variables are also all found to be statistically insignificant, with the exception of the density of retail establishments in the community where the establishment is 
located. However this finding occurs only when all HR practices are entered together, that is in the results reported in the last column.

Turning to the HRM variables we find that when they are entered separately, all the HRM variables are found to have positive coefficients and most (the exceptions being information sharing and acknowledgement) are statistically significant. Thus the findings reported in columns 2-7 provide support for diverse hypotheses, including the views that establishments with more participation on the job, greater use of development talks, more performance feedback, and practices that provide for better goal alignment between the different parties are expected to be more productive. The most precise OLS results are obtained for development talks which are statistically significant at the $1 \%$ level.

However, when all the HRM variables are entered together, from the result reported in column (8) of Table 2 we see that only one variable remains statistically significant at conventional levels, namely the measure of development talks. But as noted, many of the individual HRM practices are strongly correlated; when all are separately and simultaneously included in the same model it is difficult to estimate the parameters of the correlated variables very precisely. Our hypothesis that the HRM variables have positive performance effects is supported by an F-test comparing the full specification with a specification omitting all HRM variables. This test suggests that the null hypothesis that the HRM variables have no economic effects can be rejected at the $5 \%$ level of confidence. ${ }^{23}$

Next, we replace individual HRM practices with our summary scale of HRM practices (column 9). Consistent with the hypothesis that HRM matters for performance, the scale gets a positive coefficient that is significant, albeit only at a $10 \%$ level. In column 10 , where we include development talks, only that variable is significant at conventional levels, but the scale is not. In sum, the OLS results provide somewhat mixed evidence on the importance of HRM variables. 
Since the OLS results may be biased by time invariant unobservable differences between establishments, we also estimate fixed effects models. Table 3 reports findings from those specifications in which we include two sets of fixed effects-for establishments and managers - as well as dummy variables for each month and year. ${ }^{24}$ Reassuringly we find that the establishment dummies are found to be jointly significantly different from zero, as are the management dummies. Hence it is the findings in Table 3 that are preferred to those reported in Table 2.

[TABLE 3]

From Table 3 we see that, of the two basic inputs, only the log of hours is statistically significant and that the coefficient is smaller than in the OLS estimates. That the capital coefficients are insignificant is not altogether surprising, since the within transformation procedure uses only variation within establishments to identify the parameters. Conditional on the establishment fixed effects, the log of space does not have any predictive power since it evolves slowly over time. Also the low values for the input coefficients, especially for capital, are not unusual in a fixed effects context (see, e.g. Griliches and Mairesse, 1999). Also the variables depicting the quality of labor force are all found to be statistically insignificant. Importantly the addition of firm and management fixed effects means that we do not find (as in Table 2) that establishments with a higher share of full time workers are less productive (relative to the omitted category, the share of temporary workers.) In general, the operating environment variables are found to be insignificant with the exception of net migration and, in some specifications, net income and the density of retail establishments relative to population. Net migration has a positive sign in all estimates. The other two variables are marginally significant in some specifications.

Next we examine findings for the HRM variables, beginning first with the specifications when they are entered one at a time. Column 2 suggests that information sharing has a strong 
positive effect on sales. The standard deviation of this variable is 0.35 which means that a one standard deviation increase in this variable would lead to approximately a $2.9 \%$ increase in value added. Participation on the job has also a positive and statistically significant effect on value added, which is of similar magnitude to the impact of information sharing. This is consistent with the hypothesized effects of participation on employee motivation and learning about the content of their job. Performance feedback has a positive significant coefficient, with an impact that is of a similar magnitude to the other significant variables. The variable "acknowledgement from supervisor" has a very small positive coefficient, and it is not found to be statistically significant. Shared goals, as reported in column 7 , is also found to have a positive coefficient. Taken together the variables depicting feedback on performance are consistent with Bartel's (2004) results for banking. Her results show that feedback on performance has positive effects on performance in banking.

Column 8 reports findings when all the HRM variables are entered simultaneously. Importantly, on the basis of an F test we find that the variables in the HRM vector are jointly significantly different from zero. ${ }^{25}$ However, the findings on individual elements in the HRM vector change somewhat when all the variables are entered simultaneously. While the coefficients are quite stable, as expected, all coefficients decrease somewhat and the standard errors are much larger and none of the variables remains statistically significant at conventional levels. As already noted, the increase in the standard errors is probably due to the strong correlation between the HRM variables (and similar results have been reported by Cappelli \& Neumark, 2001). The fact that the F-test is so strongly significant also supports this view. Compared to the simple OLS results it appears that the fixed effect results for HRM variables are not strongly driven by unobserved heterogeneity.

The last two columns use the scale to describe the HRM environment. This HRM scale has a positive and statistically significant coefficient. Since its standard deviation is roughly 
0.8 , its impact on productivity is close to $3 \%$, which is an economically significant amount. Finally, in the last column of Table 3 we enter the variable "development talks" simultaneously with the HRM scale, and we find that the coefficient for the HRM scale is basically unaffected, while the coefficient for development talks is insignificant. The results suggest that when HR environments have high overall scores concerning information sharing, participation in decision making, performance feedback, acknowledgement, and shared goals, this will lead to better performance.

The first robustness check we perform reflects the fact that our data comprise a mix of variables that vary by month (such as value added and hours) and other variables that vary annually. Since this presents a potential timing problem, in Table 4 we report findings based on models in which we aggregate the performance data to an annual basis.

[Table 4]

Considering first the results in specifications in which we enter only one HRM variable at a time (and reported in columns 1-7), it is seen that often the sign and the magnitude of the coefficients reported in Table 4 are similar to those reported earlier in Table 3. For instance, the coefficient of information sharing is essentially the same. However, the coefficients for on-the-job participation and performance feedback decline somewhat and now they are not statistically significant. On the other hand, the coefficient for shared goals increases and is now significant at a $5 \%$ level of confidence. In the last two columns of Table 4 we report findings that use the scale that describes the HRM environment. Most reassuringly, the coefficients for the HRM scale are essentially unaltered from those reported in Table 3 although, reflecting a smaller number of observations, the t-statistics decline. Furthermore, when the variable "development talks" is entered simultaneously with the HRM scale again, as in Table 3, we find that the coefficient for the HRM scale is basically unaffected, while the coefficient for development talks is insignificant. 
The second robustness check stems from whether or not we can give a causal interpretation to the HRM variables and which, in turn, depends on whether or not the assumption of strict exogeneity is met. This assumption is tested by including future values of the HRM variables in the regressions reported in columns 1-8 in Table 5 where the analysis, as in Table 3, is based on monthly performance data. In the models where the variables are entered individually we include the 12 months forward value of the given HRM variable in the equation. The forward value was chosen to be 12 months forward because the variation in that variable takes place annually ${ }^{26}$. While in the main these additional variables are found to have statistically insignificant coefficients, the coefficient for the forward value of development talks is statistically significant. This suggests that prior productivity shocks have a feedback effect with development talks. With this exception, it appears that the HRM variables do not violate the assumption of strict exogeneity. The coefficients of some of the HRM variables are notably higher when compared to Table 3 . This is because we are essentially estimating the model using only the years 2001 and 2002. In other words, we would get the same results for the HRM variables if we ran the model using only years 2001 and 2002.

[Table 5]

\section{Conclusions}

By assembling a large and most unusual panel data set from a large Finnish retail firm, we provide the most reliable evidence to date for the retail industry of the impact of human resource management practices on firm performance. Our performance data are most unusual-monthly financial and performance data for the period 2001-2003 and for 47 all retail units in the case. These are combined with information for crucial aspects of HRM environments that are obtained from annual employee surveys and include data on employee participation, goal alignment and information sharing. Our rich data also include controls for crucial features of 
the operating environment and important dimensions of core inputs, notably labor, as well as a measure of output, value added, that is theoretically preferred. Our main empirical approach is to estimate augmented production functions using panel data methods that include both establishment and manager fixed effects (as well as month and year dummies) and which are augmented by different specifications of the HRM environment, and including some measures of the overall HRM climate that are derived from principal component analysis.

In general we find evidence that the HRM environment matters to business performance. This is the case across a variety of specifications, including both pooled OLS models and fixed effect models that include both establishment and manager fixed effects (as well as month and year dummies) both when HRM variables are entered separately or as a set. Importantly, in a model that includes the set of HRM variables, an F test indicates that the variables in the HRM vector are jointly significantly different from zero. And when we include a summary scale to represent the HRM variables, we find that this scale is also significant. Specifically we find that a one standard deviation increase of the scale would lead to approximately 3 per cent higher productivity. Importantly, our key findings survive exogeneity tests and additional exercises we undertake to investigate possible timing issues related to the nature of our data.

Empirical research on the productivity impact of HRM has been relatively sparse. While some previous studies have found considerable gains from participatory HRM practices (in particular Batt, 1999, 2002, and Bartel, 2004), other researchers have been more skeptical. They have also questioned whether innovative HRM can be expected to matter much in settings where relatively low-skilled employees do fairly routine tasks. Our empirical findings provide much more solid support than was previously available for those who hypothesize that novel HRM practices can be expected to be associated with enhanced business 
performance, even in settings where employee tasks are fairly simple and employees are relatively low-skilled, and in a setting that is outside North America. 


\section{References}

Appelbaum, Eileen, Thomas Bailey, Peter Berg and Arne L. Kalleberg (2000): Manufacturing Advantage. Why High-Performance Work Systems Pay Off, ILR Press Ithaca, N.Y.

Appelbaum, Eileen and Rosemary Batt (1994): The New American Workplace: Transforming Work Systems in the United States, Ithaca: ILR Press.

Arellano, Manuel (1987): Computing Robust Standard Errors for Within-Group Estimators, Oxford Bulletin of Economics and Statistics, 49: 431-434.

Banker, Rajiv D, Seok-Young Lee, Gordon Potter and Dhinu Srinivasan (1996): Contextual Analysis of Performance Impacts of Outcome-Based Incentive Compensation, Academy of Management Journal, 39(4): 920-48.

Baron, James N. and David M. Kreps. 1999. Strategic Human Resources: Frameworks for General Managers. New York: Wiley.

Bartel, Ann P. (2004): Human Resource Management and Organizational Performance:

Evidence from Retail Banking, Industrial and Labor Relations Review, 57 (2): 181-203.

Basker, Emek (2005): “Job Creation or Destruction? Labor-Market effects of Wal-Mart Expansion" Review of Economics and Statistics, 87 (1): 174-183.

Batt, Rosemary (1999): Work Organization, Technology, and Performance in Customer Service and Sales, Industrial \& Labor Relations Review, 52 (4): 539-564.

Batt, Rosemary (2002): Managing Customer Services: Human Resource Practices, Quit Rates, and Sales Growth, Academy of Management Journal, 45(3): 587-97.

Bell, Simon and Bulent Menguc (2002): The Employee-Organization Relationship, Organization Citizenship Behaviours, and Superior Service Quality, Journal of Retailing 78 (2): 131-146. 
Benabou, Roland and Jean Tirole (2003): Intrinsic and Extrinsic Motivation, Review of Economic Studies, 70 (July): 489-520.

Ben-Ner, Avner and Derek C. Jones (1995) Employee Participation, Ownership, and Productivity: A Theoretical Framework. Industrial Relations, 34 (4): 532-554

Ben-Ner, Avner, Fanmin Kong and Stacie Bosley (1999) "Workplace Organization and Human Resource Practices: The Retail Food Industry." University of Minnesota, Retail Food Industry Center, Working Paper 00-01, December.

Bertrand, Marianne, Esther Duflo, and Sendhil Mullainathan (2004): How Much Should We Trust Difference-in-Differences Estimates?, Quarterly Journal of Economics, 119 (1): 249275.

Bitner, Mary Jo (1992): Servicescapes: The Impact of Physical Surroundings on Customers and Employees, Journal of Marketing, 56 (2): $57-71$.

Blasi, Joseph R. and Douglas L. Kruse (2006): 'U.S. High Performance Work Practice's at Century's End', Industrial Relations, 45(4): 547-578.

Böckerman, Petri and Roope Uusitalo (2006): 'Erosion of the Ghent System and Union Membership Decline: Lessons from Finland', British Journal of Industrial Relations, 44(2): $283-303$.

Bonin, John P., Derek C. Jones and Louis Putterman (1993): Theoretical and Empirical Studies of Producer Cooperatives: Will Ever the Twain Meet?, Journal of Economic Literature, 31 (3): 1290-1320.

Borin, Norm and Paul Farris (1995): A Sensitivity Analysis of Retail Shelf Management Models, Journal of Retailing, 1995 (2): 153-171.

Cameron A. Colin and Pravin K. Trivedi (2005): Microeconometrics: Methods and Applications, New York: Cambridge University Press. 
Cappelli, Peter and David Neumark (2001): Do "High-Performance" Work Practices Improve Establishment-Level Outcomes?, Industrial and Labor Relations Review, 54 (4): 737-775.

Chatterjee, Samprit and Ali S. Hadi (1986): Influential Observations, High Leverage Points, and Outliers in Linear Regression, Statistical Science, 1 (3): 379-393.

Delery, John E. and D. Harold Doty (1996): Modes of Theorizing in Strategic Human Resource Management: Tests of Universalistic, Contingency, and Configurational Performance Predictions, Academy of Management Journal, 39 (4): 802 - 35.

Griliches, Zvi and Jaqcues Mairesse (1999): Production Functions: Search for Identification, in Steinar Strom (ed.), Econometrics and Economic Theory in the 20th Century: The Ragnar Frisch Centennial Symposium. Economic Society Monograph Series (No.31). New York: Cambridge University Press.

Foster, Lucia, John Haltiwanger and C.J. Krizan (2002): The Link Between Aggregate and Micro Productivity Growth: Evidence from Retail Trade. NBER WP 9120, August.

Hamilton, Barton H., Jack A. Nickerson, and Hideo Owan (2003): Team Incentives and Worker Heterogeneity: An Empirical Analysis of the Impact of Teams on Productivity and Participation, Journal of Political Economy, 111 (3): 465-497.

Harley, Bill (2005): Hope or Hype? High Performance Work Systems, in Jeff Hyman, Paul Thompson and Bill Harley (eds.) Participation and Democracy at Work: Essays in Honour of Harvie Ramsay, Palgrave Macmillan.

Heller, Frank, Eugen Pusic, George Strauss and Bernhardt Wilpert (1998): Organizational Participation: Myth or Reality? Oxford: Oxford University Press.

Hellerstein, Judith K. and David Neumark (1999): Wages, Productivity, and Worker Characteristics: Evidence from Plant-Level Production Functions and Wage Equations, Journal of Labor Economics, 17 (3): 409-446 
Huselid, Mark A. (1995): The Impact of Human Resource Management Practices on Turnover, Productivity, and Corporate Financial Performance, Academy of Management Journal, 38 (3): 635-672.

Huselid, Mark A., and Brian E. Becker (1996): Methodological Issues in Cross-Sectional and Panel Estimates of the Human Resource-Firm Performance Link, Industrial Relations, 35 (3): 400-422.

Ichniowski, Casey and Kathryn Shaw (2003): Beyond Incentive Pay: Insiders' Estimates of the Value of Complementary Human Resource Management Practices, Journal of Economic Perspectives, 17 (1): 155-80.

Ichniowski, Casey, Kathryn Shaw and Giovanna Prennushi (1997): The Effects of Human Resource Management on Productivity, American Economic Review, 87 (June): 291-313.

Ilmakunnas, Pekka, Mika Maliranta and Jari Vainiomäki (2004): The Roles of Employer and Employee Characteristics for Plant Productivity, Journal of Productivity Analysis, 21 : 249276.

Jalava, Jukka (2005): Growth and Productivity in the Finnish Trade Industry, 1975-2003: A National Comparative Perspective, EU KLEMS project working paper nr. 2.

Jones, Derek C. (1987): The Productivity Effects of Worker Directors and Financial Participation in the Firm: The Case of British Retail Cooperatives, Industrial and Labor Relations Review, 41 (1): 79-92.

Jones, Derek C., Panu Kalmi and Mikko Mäkinen (2006): 'The Determinants of Stock Option Compensation: Evidence from Finland', Industrial Relations, 45 (3): 437 - 468.

Jones, Derek C. and Takao Kato (2004): The Effects of Employee Involvement in Firm Performance: Evidence from an Econometric Case Study, working paper, Hamilton College. 
Kalmi, Panu and Antti Kauhanen (2005): 'Workplace Innovations and Employee Outcomes:

Evidence from a Representative Employee Survey', SKOPE Research Papers 61, Oxford University.

Kato, Takao (2006): 'Determinants of the Extent of Participatory Employment Practices:

Evidence from Japan', Industrial Relations, 45(4): 579 - 605.

Kauhanen, Antti (2006): The Determinants of Incidence of Workplace Innovations: Evidence from an Employee Survey, manuscript, Helsinki School of Economics.

Keaveney, Susan (1995): Customer Switching Behavior in Service Industries: An Exploratory Study, Journal of Marketing, 59 (2): $71-82$.

Kezdi, Gabor (2004): Robust Standard Error Estimation in Fixed-Effects Panel Models, Hungarian Statistical Review, 9: 95-119.

Kruse, Douglas (1993) Profit Sharing: Does it make a Difference? Kalamazoo, MI. W.E. Upjohn Institute.

Lazear, Edward P. (2000): Performance Pay and Productivity, American Economic Review, $90(5): 1346-1361$

Levine, David I. (1995) Reinventing the Workplace: How Business and Employees Can Both $\underline{\text { Win, }}$ Washington, D.C.: Brookings.

MacDuffie, John Paul (1995) 'Human Resource Bundles and Manufacturing Performance: Organizational Logic and Flexible Production Systems in the World Auto Industry', Industrial and Labor Relations Review, 48:197-221.

Mankinen, Reijo, Petri Rouvinen and Pekka Ylä-Anttila (2002): Palveluiden tuottavuus kilpailu ja teknologia muuttavat rakenteita, The Research Institute of the Finnish Economy, Discussion Paper nr. 829. 
Mardia, Kanti V., John T. Kent, and John M. Bibby (1979): Multivariate Analysis. London: Academic Press.

Neumark, David, Junfu Zhang, and Stephen Ciccarella (2005): The Effects of Wal-Mart on Local Labor Markets, NBER Working Papers 11782, National Bureau of Economic Research.

Osterman, Paul (1994): How Common is Workplace Transformation and Who Adopts it?, Industrial and Labor Relations Review, 47 (2): 173-188.

Osterman, Paul (2000): "Work Reorganization in an Era of Restructuring: Trends in Diffusion and Effects on Employee Welfare", Industrial and Labor Relations Review, 53 (2): 179-196.

Preuss, Gil A. (2003): High Performance Work systems and Organizational Outcomes: The Mediating Role of Information Quality, Industrial and Labor Relations Review; 56 (4): 590 605

Reardon, James, John Hasty, and Barbara Coe (1996): The Effect of Information Technology on Productivity in Retailing, Journal of Retailing, 72 (4):445-461.

Simonson, Itamar (1999): The Effect of Product Assortment on Buyer Preferences, Journal of Retailing, 75 (3) 347-370.

Wooldridge, Jeffrey (2002): Econometric Analysis of Cross Section and Panel Data, Cambridge. MIT Press 
TABLE 1

Descriptive statistics

\begin{tabular}{|c|c|c|c|}
\hline Variable & Obs & Mean & Standard deviation \\
\hline \multicolumn{4}{|l|}{ Inputs and Outputs } \\
\hline Log Value added & 1471 & 7.82 & 0.46 \\
\hline Log Hours & 1467 & 8.90 & 0.33 \\
\hline Log Space $(\mathrm{m} 2)$ & 1471 & 7.51 & 0.38 \\
\hline \multicolumn{4}{|l|}{ Personnel } \\
\hline Share of male workers & 1471 & 0.13 & 0.05 \\
\hline Share of permanent part time workers & 1471 & 0.49 & 0.12 \\
\hline Share of permanent full time workers & 1471 & 0.21 & 0.06 \\
\hline Share of temporary workers & 1471 & 0.31 & 0.11 \\
\hline Average tenure (years) & 1471 & 6.68 & 3.27 \\
\hline \multicolumn{4}{|l|}{ Environment } \\
\hline Population density & 1471 & 0.42 & 0.58 \\
\hline Net migration & 1471 & 0.00 & 0.01 \\
\hline Net income & 1471 & 0.11 & 0.01 \\
\hline Share of highly educated & 1471 & 0.10 & 0.03 \\
\hline Home ownership & 1471 & 0.56 & 0.06 \\
\hline Retail establishments/habitants & 1471 & 0.01 & 0.00 \\
\hline Average turnover of retail establishments & 1471 & 0.01 & 0.00 \\
\hline \multicolumn{4}{|l|}{ HRM } \\
\hline Information sharing & 1471 & 3.78 & 0.35 \\
\hline Participation on the job & 1471 & 3.85 & 0.36 \\
\hline Development talks & 1471 & 0.81 & 0.22 \\
\hline Performance feedback & 1471 & 3.99 & 0.34 \\
\hline Supervisor acknowledgement & 1471 & 3.89 & 0.42 \\
\hline Shared goals & 1471 & 4.27 & 0.36 \\
\hline Principal component score 1 & 1471 & 0.00 & 1.90 \\
\hline Principal component score 2 & 1471 & 0.00 & 1.00 \\
\hline Principal component score 3 & 1471 & 0.00 & 0.76 \\
\hline Principal component score 4 & 1471 & 0.00 & 0.61 \\
\hline Scale & 1471 & 0.00 & 0.83 \\
\hline
\end{tabular}

Notes. 1) See Section IV for details of the HRM variable definitions.

2) All monetary values are in real terms and measured in euros. The deflator is monthly consumer price index, where Jan. $2000=100$.

3) Population density=population (in thousands)/area

Net migration $=($ net internal migration + immigration-emigration $) /$ population

Net income $=$ net taxable income (in hundreds of thousands)/population

Highly educated means persons having a university degree.

Average turnover of retail establishments is in hundreds of millions of euros. 
TABLE 2

\begin{tabular}{|c|c|c|c|c|c|c|c|c|c|c|}
\hline \\
\hline & (1) & (2) & (3) & (4) & $(5)$ & (6) & $(7)$ & (8) & (9) & (10) \\
\hline \multirow[t]{2}{*}{ Log Hours } & $0.863 * * *$ & $0.853^{* * *}$ & $0.849 * * *$ & $0.856^{* * *}$ & $0.838^{* * *}$ & $0.859^{* * *}$ & $0.858 * * *$ & $0.836^{* * *}$ & $0.846^{* * *}$ & $0.844 * * *$ \\
\hline & {$\left[\begin{array}{lll}11 & 58\end{array}\right]$} & [11.15] & {$[11.40]$} & {$[10.87]$} & {$[11.02]$} & {$[11.23]$} & {$[11.32]$} & {$[11.08]$} & {$[10.95]$} & [10.82] \\
\hline \multirow[t]{2}{*}{ Log Space } & $0.178^{* *}$ & $0.190^{* * *}$ & $0.181^{* * *}$ & $0.168^{* *}$ & $0.185^{* * *}$ & $0.185^{* *}$ & $0.180^{* *}$ & $0.170^{* *}$ & $0.189^{* * *}$ & $0.177 * * *$ \\
\hline & {$[2.62]$} & {$[2.84]$} & {$[2.81]$} & {$[2.50]$} & [2.83] & {$[2.67]$} & {$[2.68]$} & {$[2.53]$} & {$[2.87]$} & {$[2.73]$} \\
\hline \multirow[t]{2}{*}{ Share of male workers } & 0.292 & 0.289 & 0.374 & 0.327 & 0.362 & 0.301 & 0.292 & 0.416 & 0.33 & 0.35 \\
\hline & {$[0.80]$} & {$[0.78]$} & {$[0.96]$} & {$[0.87]$} & {$[0.92]$} & {$[0.81]$} & {$[0.77]$} & {$[1.01]$} & {$[0.85]$} & {$[0.90]$} \\
\hline \multirow[t]{2}{*}{ Share of part time workers } & 0.058 & 0.06 & 0.054 & 0.046 & 0.076 & 0.052 & 0.049 & 0.06 & 0.056 & 0.046 \\
\hline & {$[0.49]$} & {$[0.50]$} & {$[0.45]$} & {$[0.44]$} & {$[0.64]$} & {$[0.45]$} & {$[0.41]$} & {$[0.55]$} & {$[0.47]$} & {$[0.43]$} \\
\hline \multirow[t]{2}{*}{ Share of full time workers } & $-0.678^{* * * *}$ & $-0.683^{* * *}$ & $-0.721^{* * *}$ & $-0.742^{* * *}$ & $-0.655^{* * *}$ & $-0.687^{* * *}$ & $-0.687^{* * * *}$ & $-0.735 * * *$ & $-0.691^{* * *}$ & $-0.743^{* * *}$ \\
\hline & {$[2.84]$} & {$[2.85]$} & {$[3.10]$} & {$[3.20]$} & {$[2.73]$} & {$[2.80]$} & {$[2.85]$} & {$[3.24]$} & {$[2.87]$} & {$[3.25]$} \\
\hline \multirow[t]{2}{*}{ Average tenure (months) } & $0.014^{* *}$ & $0.013^{* *}$ & $0.015^{* *}$ & $0.014^{* * *}$ & $0.014^{* *}$ & $0.013^{* *}$ & $0.013^{* *}$ & $0.015 * * *$ & $0.013^{* *}$ & $0.013^{* *}$ \\
\hline & {$[2.42]$} & {$[2.24\}$} & {$[2.60]$} & {$[2.72]$} & {$[2.33]$} & {$[2.37]$} & {$[2.34]$} & {$[2.71]$} & {$[2.32]$} & {$[2.60]$} \\
\hline \multirow[t]{2}{*}{ Population density } & -0.025 & -0.026 & -0.032 & -0.015 & -0.027 & -0.03 & -0.03 & -0.02 & -0.031 & $-0.02 i$ \\
\hline & {$[0.51]$} & {$[0.52]$} & {$[064]$} & {$[0.29]$} & {$[0.55]$} & {$[0.60]$} & {$[0.59]$} & {$[0.37]$} & {$[0.62]$} & {$[0.39]$} \\
\hline \multirow[t]{2}{*}{ Net migration } & -2.101 & -2.593 & -2.527 & -1.401 & -2.885 & -2.252 & -2.559 & -2.088 & -2.833 & -2 \\
\hline & {$[0.54]$} & {$[0.65]$} & {$[0.64]$} & {$[0.37]$} & {$[0.73]$} & {$[0.57]$} & {$[0.63]$} & {$[0.53]$} & {$[0.70]$} & {$[0.51]$} \\
\hline \multirow[t]{2}{*}{ Net income } & -3.545 & -2.924 & -2.262 & -2.973 & -2.032 & -2.939 & -2.855 & -1.653 & -2.103 & -2.028 \\
\hline & {$[156]$} & {$[1.26]$} & {$\left[\begin{array}{ll}1 & 03\end{array}\right]$} & {$[1.48]$} & {$[0.84]$} & {$[131]$} & [1.23] & {$[0.77]$} & {$[0.91]$} & {$[0.97]$} \\
\hline \multirow[t]{2}{*}{ Share of highly educated } & 0.446 & 0.43 & 0.365 & 0.417 & 0.444 & 0.392 & 0.527 & 0.398 & 0.425 & 0.406 \\
\hline & {$\left[\begin{array}{ll}0 & 38\end{array}\right]$} & {$[0.37]$} & {$[0.33]$} & {$[0.40]$} & {$[0.38]$} & {$[0.34]$} & {$[0.45]$} & {$[0.39]$} & {$[0.37]$} & {$[0.39]$} \\
\hline \multirow[t]{2}{*}{ Home ownerhip } & -0.07 & -0.054 & -0.154 & -0.052 & -0.068 & -0.088 & -0.043 & -0.098 & -0.08 & -0.061 \\
\hline & {$[0.14]$} & {$[0.11]$} & {$[0.32]$} & {$[0.11]$} & {$[0.13]$} & {$[0.17]$} & {$[0.09]$} & {$[0.21]$} & {$[0.16]$} & {$[0.13]$} \\
\hline \multirow[t]{2}{*}{ Retail establishments/habitants } & -27.093 & -29.394 & -30.611 & $-33656^{*}$ & -29.177 & -26.168 & -26.249 & $-35.558^{*}$ & -28.683 & $-33.983^{*}$ \\
\hline & {$[1.39]$} & {$[1.51]$} & {$[1.58]$} & {$[1.77]$} & {$[1.52]$} & {$[1.37]$} & {$[1.38]$} & {$[1.95]$} & {$[1.49\}$} & {$[1.81]$} \\
\hline \multirow[t]{2}{*}{ Average turnover of retail establishme: } & 1.731 & 1.967 & 3.281 & 0.317 & 6.418 & 3.568 & 3367 & 4.17 & 4.698 & 2.576 \\
\hline & {$\left[\begin{array}{ll}0 & 14\end{array}\right]$} & {$[0.16]$} & [0.29] & {$[0.03]$} & {$[0.54]$} & {$[0.30]$} & {$[0.29]$} & {$[0.36]$} & {$[0.41]$} & {$[0.22]$} \\
\hline \multirow[t]{2}{*}{ Information sharing } & & 0.044 & & & & & & -0.015 & & \\
\hline & & {$[1.14]$} & & & & & & {$[0.31]$} & & \\
\hline \multirow[t]{2}{*}{ Participation on the job } & & & $0.084^{* *}$ & & & & & 0.045 & & \\
\hline & & & {$[2.35]$} & $0.163^{* * *}$ & & & & $\begin{array}{c}{[0.96]} \\
0.139^{* *}\end{array}$ & & $0.143^{* *}$ \\
\hline Development talks & & & & $\begin{array}{c}0.163^{3 * *} \\
{[2.83]}\end{array}$ & & & & [2.15] & & {$[2.27]$} \\
\hline \multirow[t]{2}{*}{ Performance feedback } & & & & & $0.086^{*}$ & & & 0.063 & & \\
\hline & & & & & {$[1.70]$} & & & {$[1.14]$} & & \\
\hline \multirow[t]{2}{*}{ Supervisor acknowledgement } & & & & & & 0.037 & & -0.01 & & \\
\hline & & & & & & {$\left[\begin{array}{ll}1 & 15\end{array}\right]$} & & {$[0.28]$} & & \\
\hline Shared goals & & & & & & & $0.053^{*}$ & 0 & & \\
\hline & & & & & & & {$[1.70]$} & {$[0.00]$} & & \\
\hline Scale & & & & & & & & & $0.034^{*}$ & 0.024 \\
\hline & & & & & & & & & {$[1.90]$} & {$[1.23]$} \\
\hline Observations & 1467 & 1467 & 1467 & 1467 & 1467 & 1467 & 1467 & 1467 & 1467 & 1467 \\
\hline R-squared & 0.861 & 0.862 & 0.864 & 0.866 & 0.863 & 0.862 & 0.862 & 0.867 & 0.863 & 0.867 \\
\hline Number of establishments & 47 & 47 & 47 & 47 & 47 & 47 & 47 & 47 & 47 & 47 \\
\hline Notes. 1) Coefficients are reported in th & he table and & t-statistics & rackets. & & & & & & & \\
\hline 2) Significance of the varibles is indic & ated as tollo & 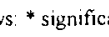 & at $10 \%$, & & & & & & & \\
\hline 3) The t-statistics are robust to heteroso & cedasticity a & d autocor & tion within & each estab & nent & & & & & \\
\hline 4) The specifications include a constan & it as well as & month and $y$ & $r$ dummies. & & & & & & & \\
\hline 5) R-squared is unadjusted & & & & & & & & & & \\
\hline
\end{tabular}


TABLE 3

The Impact of HRM on Productivity: Estimates Including Establishment Fixed Effects and Manager Dummies

\begin{tabular}{|c|c|c|c|c|c|c|c|c|c|c|}
\hline & (1) & (2) & (3) & (4) & (5) & (6) & (7) & $(8)$ & (9) & (10) \\
\hline \multirow[t]{2}{*}{ Log Hours } & $0.263^{* * *}$ & $0.266^{* * *}$ & $0.266 * * *$ & $0.264^{* * *}$ & $0.261 * * *$ & $0.264^{* * *}$ & $0.267^{* * *}$ & $0.266^{* * *}$ & $0.267^{* * *}$ & $0.267^{* * *}$ \\
\hline & {$[9.59]$} & {$[9.90]$} & [9.99] & {$[9.53]$} & {$[9.65]$} & [9.58] & {$[9.64]$} & {$[10.10]$} & {$[9.73]$} & {$[9.70]$} \\
\hline \multirow[t]{2}{*}{ Log Space } & 0.075 & 0.074 & 0.054 & 0.062 & 0.025 & 0.074 & 0.065 & 0.031 & 0.048 & 0.04 \\
\hline & {$[0.92]$} & {$[0.93]$} & {$[0.68]$} & {$[0.77]$} & {$[0.29]$} & {$[0.88]$} & {$[0.72]$} & {$[0.40]$} & {$[0.55]$} & {$[0.48]$} \\
\hline \multirow[t]{2}{*}{ Share of male workers } & 0.381 & 033 & 0.241 & 0.349 & 0.372 & 0.355 & 0.253 & 0.281 & 0.217 & 0.202 \\
\hline & {$[1.10]$} & {$[0.96]$} & {$[0.80]$} & {$[0.98]$} & {$[1.20]$} & {$[1.01]$} & {$[0.70]$} & {$[0.90]$} & {$[0.68]$} & {$[0.62]$} \\
\hline \multirow[t]{2}{*}{ Share of part time workers } & 0.062 & 0.013 & 0.003 & 0.067 & 0.054 & 0.05 & 0.032 & 0.021 & -0.004 & 0.002 \\
\hline & {$[0.63]$} & {$[0.13]$} & {$[0.03]$} & $\{0.69\}$ & {$[0.54]$} & {$[0.50]$} & {$\left[\begin{array}{lll}0 & 3 & 1\end{array}\right]$} & {$\left[\begin{array}{ll}0 & 21\end{array}\right]$} & {$[0.04]$} & {$[0.02]$} \\
\hline \multirow[t]{2}{*}{ Share of full time workers } & 0.173 & 0.174 & 0.114 & 0.067 & 0.115 & 0.151 & 0.166 & 0.059 & 0.106 & 0.037 \\
\hline & {$[0.39]$} & {$[0.40]$} & {$[0.27]$} & {$[0.16]$} & {$[0.26]$} & {$[0.35]$} & {$[0.35]$} & {$[0.16]$} & {$[0.23]$} & {$[0.09]$} \\
\hline \multirow{2}{*}{ Average tenure (months) } & 0.039 & 0.034 & 0.036 & 0.035 & 0.038 & 0.04 & 0041 & 0029 & 0.039 & 0.037 \\
\hline & {$[1.49]$} & {$\left[\begin{array}{ll}1 & 29\end{array}\right]$} & {$[1.45]$} & {$[1.37]$} & {$[1.47]$} & {$[1.54]$} & {$[1.53]$} & [1.14] & {$[1.48]$} & {$[1.40]$} \\
\hline \multirow[t]{2}{*}{ Population density } & 1.287 & 2.954 & 3.657 & 2.223 & 2.199 & 1.412 & 1.673 & 4.611 & 2.973 & 3.531 \\
\hline & {$[0.31]$} & {$[0.72]$} & {$[0.89]$} & {$[0.52]$} & {$[0.52]$} & {$[0.34]$} & {$[0.40]$} & {$[1.15]$} & {$[0.71]$} & {$[0.84]$} \\
\hline \multirow[t]{2}{*}{ Net migration $\%$} & $5.604^{* *}$ & $5.815^{* *}$ & $6.098^{* *}$ & $6085^{* * *}$ & $5.888^{* *}$ & $5.486^{* *}$ & $5.237^{* *}$ & $6.698^{* * *}$ & $5.478^{* *}$ & $5.807^{* *}$ \\
\hline & {$[2.55]$} & {$[2.53]$} & {$[2.64]$} & {$[2.71]$} & {$[2.34]$} & {$[2.36]$} & {$[2.31]$} & {$[2.94]$} & {$[2.23]$} & {$[2.35]$} \\
\hline \multirow[t]{2}{*}{ Net income } & 4.427 & $12.325^{*}$ & $12.809^{*}$ & 3.784 & 8.968 & 4.745 & 6.805 & $14.828^{*}$ & 11.675 & 10.941 \\
\hline & {$[0.63]$} & {$[1.7 !]$} & {$[1.77]$} & {$[0.55]$} & {$[1.19]$} & {$[0.67]$} & {$[0.92]$} & {$[1.94]$} & {$[1.56]$} & {$[1.45]$} \\
\hline \multirow[t]{2}{*}{ Share of highly educated } & -3.104 & -1.802 & -2.149 & -2.291 & -3.14 & -3.907 & -2.761 & 0.447 & -3.458 & -2.897 \\
\hline & {$[0.47]$} & {$[0.31]$} & {$[0.33]$} & {$[0.34]$} & {$[0.48]$} & {$[0.60]$} & {$[0.42]$} & {$[0.08]$} & {$[0.55]$} & {$[0.46]$} \\
\hline \multirow[t]{2}{*}{ Home ownerhip \% } & 0.02 & 0.158 & 0023 & 0.296 & 0.152 & -0.076 & -0.077 & 0.609 & -0.101 & 0.089 \\
\hline & {$[0.03]$} & {$[0.22]$} & {$[0.04]$} & {$[0.38]$} & {$[0.23]$} & {$[0.10]$} & {$[0.11]$} & {$[0.71]$} & {$[0.14]$} & {$[0.11]$} \\
\hline \multirow[t]{2}{*}{ Retail establishments/habitants } & $72.638^{*}$ & 54.504 & 64.039 & $87.747^{* *}$ & 46.983 & $74.385^{*}$ & 57.722 & 53.043 & 52.6 & 63.588 \\
\hline & {$[187]$} & {$[1.63]$} & {$[165]$} & {$[2.13]$} & {$[1.17]$} & {$[1.86]$} & {$[1.33]$} & {$[1.04]$} & {$[1,36]$} & {$[1.49]$} \\
\hline \multirow[t]{2}{*}{ Average turnover of retail establishments } & -6.269 & -14.997 & -14.485 & -2.53 & -6.042 & -6.968 & $-3.84 !$ & -10.557 & -10.1 & -7.428 \\
\hline & {$[0.26]$} & {$[0.72]$} & {$[0.66]$} & {$[0.10]$} & {$[0.29]$} & {$[0.29]$} & {$[0.17]$} & {$[0.54]$} & {$[0.48]$} & {$[0.34]$} \\
\hline Information sharing & & $\begin{array}{c}0.082 * * * \\
{[3.32]}\end{array}$ & & & & & & $\begin{array}{c}0.062 \\
{[1.66]}\end{array}$ & & \\
\hline \multirow[t]{2}{*}{ Participation on the job } & & & $0.077^{* * *}$ & & & & & 0.028 & & \\
\hline & & & {$[2.79]$} & & & & & {$[0.62]$} & & \\
\hline \multirow[t]{2}{*}{ Development talks } & & & & 0.059 & & & & 0.058 & & 0.04 \\
\hline & & & & {$[1.43]$} & & & & {$[1.15]$} & & {$[0.99]$} \\
\hline \multirow[t]{2}{*}{ Performance feedback } & & & & & $0.081^{*}$ & & & 0,039 & & \\
\hline & & & & & {$[1.87]$} & & & {$[0.92]$} & & \\
\hline \multirow[t]{2}{*}{ Supervisor acknowledgement } & & & & & & 0.012 & & -0.022 & & \\
\hline & & & & & & {$[0.50]$} & & {$[0.61]$} & & \\
\hline \multirow[t]{2}{*}{ Shared goals } & & & & & & & $0.034^{*}$ & 0.005 & & \\
\hline & & & & & & & {$[1.81]$} & {$[0.17]$} & & \\
\hline \multirow[t]{2}{*}{ Scale } & & & & & & & & & $0.037 * *$ & $0.035^{* *}$ \\
\hline & & & & & & & & & {$[2.67]$} & {$[2.41]$} \\
\hline Observations & 1467 & 1467 & 1467 & 1467 & 1467 & 1467 & 1467 & 1467 & 1467 & 1467 \\
\hline R-squared & 0.864 & 0.866 & 0.866 & 0.864 & 0.865 & 0.864 & 0.864 & 0.867 & 0.866 & 0.866 \\
\hline Number of establishments & 47 & 47 & 47 & 47 & 47 & 47 & 47 & 47 & 47 & 47 \\
\hline
\end{tabular}

Notes. 1) Coefficients are reported in the table and $t$-statistics in brackets.

2) Significance of the varibles is indicated as follows: * significant at $10 \%$; ** significant at $5 \%$; *** significant at $1 \%$.

3)The t-statistics are robust to heteroscedasticity and autocorrelation within each establishment

4) The specifications include a constant, manager dummies, and month and year dummies.

5) R-squared is the unadjusted within R-squared 
TABLE 4

The Impact of HRM on Productivity Using Annual Data: Fixed Effects \& Manager Effects

\begin{tabular}{|c|c|c|c|c|c|c|c|c|c|c|}
\hline & (1) & (2) & (3) & (4) & (5) & (6) & (7) & (8) & (9) & (10) \\
\hline \multirow[t]{2}{*}{ Log Hours } & $0.554^{* * *}$ & $0.538 * * *$ & $0.560^{* * *}$ & $0.550^{* * *}$ & $0.534^{* * *}$ & $0.554^{* * *}$ & $0.633 * * *$ & $0.612^{* * *}$ & $0.576^{* * * *}$ & $0.569^{* * *}$ \\
\hline & {$\left[\begin{array}{ll}3 & 12\end{array}\right]$} & [3.28] & {$[3.35]$} & {$[3.04]$} & {$[2.95]$} & {$[3.12]$} & [3.37] & {$[3.29]$} & {$[3.43]$} & {$[3.29]$} \\
\hline \multirow[t]{2}{*}{ Log Space } & 0.095 & 0.084 & 0.077 & 0.098 & 0.053 & 0.094 & 0.067 & 0.061 & 0.059 & 0.065 \\
\hline & [1.24] & {$[1.12]$} & {$[1.02]$} & {$[1.27]$} & {$[0.66]$} & {$[1.22]$} & {$[0.79]$} & {$[0.81]$} & {$[0.73]$} & {$[0.79]$} \\
\hline \multirow[t]{2}{*}{ Share of male workers } & 0.481 & 0.423 & 0.36 & 0.487 & 0.46 & 0.467 & 0.267 & 0.309 & 0.3 & 0.306 \\
\hline & {$[1,13]$} & {$[0.90]$} & {$[0,88]$} & [1.13] & {$[1.19]$} & {$[1.06]$} & {$[0.60]$} & {$[0.72]$} & {$[0.71]$} & {$[0.73]$} \\
\hline \multirow[t]{2}{*}{ Share of part time workers } & 0.067 & 0.031 & 0.025 & 0.065 & 0.064 & 0.059 & 0.021 & 0.036 & 0.006 & 0 \\
\hline & {$[0.66\rceil$} & {$[0.27]$} & {$[0.26]$} & {$[0.62]$} & {$[0.61]$} & {$[0.61]$} & {$[0.19]$} & {$[0.25]$} & {$[0.06]$} & {$[0.00]$} \\
\hline \multirow[t]{2}{*}{ Share of full time workers } & 0.083 & 0.137 & 0.075 & 0.114 & 0.089 & 0.074 & 0.066 & 0.225 & 0.069 & 0.127 \\
\hline & {$[0.18]$} & {$[0.29]$} & {$[0.17]$} & {$[0.24]$} & {$[0.20]$} & {$[0.17]$} & {$[0.14]$} & {$[0.49]$} & {$[0.15]$} & {$[0.26]$} \\
\hline \multirow[t]{2}{*}{ Average tenure (months) } & 0.004 & 0.003 & 0.004 & 0.004 & 0.004 & $0.004^{\star}$ & $0.004^{*}$ & 0.003 & 0.004 & 0.004 \\
\hline & {$[1,62]$} & {$[1.44]$} & {$[1.56]$} & {$[1.63]$} & {$[1.60]$} & {$[1.69]$} & {$[1.69]$} & {$[1.38]$} & {$[1.60]$} & [1.65] \\
\hline \multirow[t]{2}{*}{ Population density } & $-0.011 *$ & -0.008 & -0.009 & $-0.011^{*}$ & $-0.010^{*}$ & $-0.011 *$ & $-0.009^{*}$ & -0.007 & -0.008 & -0.009 \\
\hline & {$[1.90]$} & [1.53] & {$[1,60]$} & {$[190]$} & {$[1.68]$} & {$[1.89]$} & {$[1.72]$} & {$[1.47]$} & {$[1.55]$} & [1.59] \\
\hline \multirow[t]{2}{*}{ Net migration } & 3.317 & 3.899 & 3.992 & 3.173 & 3.821 & 3.258 & 3.086 & 4.304 & 3.672 & 3.415 \\
\hline & {$[1.07]$} & [1.23] & {$[1.28]$} & {$[1.00]$} & {$[1.14]$} & {$[1.01]$} & {$[0.93]$} & {$[1.29]$} & {$[1.08]$} & {$[0.99]$} \\
\hline \multirow[t]{2}{*}{ Net income } & -15.42 & -4.156 & -6.276 & -15.177 & -8.361 & -15.101 & -8.908 & 3.016 & -3.639 & -2.835 \\
\hline & {$[1.31]$} & {$[0.30]$} & {$[0.47]$} & {$[1.25]$} & {$[0.64]$} & {$[1.28]$} & {$[0.69]$} & {$[0.19]$} & {$[0.27]$} & {$[0.20]$} \\
\hline \multirow[t]{2}{*}{ Share of highly educated } & 3.649 & 4.637 & 4.984 & 3.384 & 4.534 & 3.219 & 4.403 & 7.745 & 4.058 & 3.577 \\
\hline & {$[0.46]$} & {$[0.65]$} & {$[0.60]$} & {$[0.43]$} & {$[0.56]$} & {$[0.40]$} & {$[0.58]$} & {$[0.99]$} & {$[0.53]$} & {$[0.48]$} \\
\hline \multirow[t]{2}{*}{ Home ownerhip } & 0.611 & 0.869 & 0.623 & 0.53 & 0.762 & 0.553 & 0.504 & 0.847 & 0.561 & 0.408 \\
\hline & {$[0.78]$} & {$[0.98]$} & {$[0.80]$} & {$[0.63]$} & {$[1.00]$} & {$[0.66]$} & {$[0.61]$} & {$[0.87]$} & {$[0.67]$} & {$[0.46]$} \\
\hline \multirow[t]{2}{*}{ Retail establishments/habitants } & 48.748 & 29.716 & 44.604 & 44.053 & 29.745 & 49.826 & 29.315 & -27.064 & 31.289 & 22.025 \\
\hline & {$[1.27]$} & {$[0.86]$} & {$[1.18]$} & {$[1.05]$} & {$[0.72]$} & $\{1.27\}$ & {$[0.70]$} & {$[0.43]$} & {$[0.84]$} & {$[0.51]$} \\
\hline \multirow[t]{2}{*}{ Average turnover of retail establishments } & 0.023 & 0.016 & 0.015 & 0.021 & 0.022 & 0.022 & 0.023 & 0.015 & 0.017 & 0.014 \\
\hline & {$[0.65]$} & {$[0.46]$} & {$[0.42]$} & {$[0.60]$} & {$[0.69]$} & $\{0.63\}$ & {$[068]$} & {$[0.46]$} & {$[0.50]$} & {$[0.41]$} \\
\hline \multirow[t]{2}{*}{ Information sharing } & & $0.081^{* *}$ & & & & & & 0.051 & & \\
\hline & & {$[2.30]$} & & & & & & {$[0.91]$} & & \\
\hline \multirow[t]{2}{*}{ Participation on the job } & & & 0.05 & & & & & 0.005 & & \\
\hline & & & {$[1.40]$} & & & & & {$[0.10]$} & & \\
\hline \multirow[t]{2}{*}{ Development talks } & & & & -0.018 & & & & -0.051 & & -0.033 \\
\hline & & & & {$[0.28]$} & & & & {$[0.81]$} & & {$[0.56]$} \\
\hline \multirow[t]{2}{*}{ Performance feedback } & & & & & 0.066 & & & 0.013 & & \\
\hline & & & & & {$[1,40]$} & & & {$[0.27]$} & & \\
\hline \multirow[t]{2}{*}{ Supervisor acknowledgement } & & & & & & 0.008 & & -0.034 & & \\
\hline & & & & & & {$[0.26]$} & & {$[0.89]$} & & \\
\hline \multirow[t]{2}{*}{ Shared goals } & & & & & & & $0.052 * *$ & 0.053 & & \\
\hline & & & & & & & {$[2.11]$} & {$[1.46]$} & & \\
\hline \multirow[t]{2}{*}{ Scale } & & & & & & & & & $0.036^{*}$ & $0.037^{*}$ \\
\hline & & & & & & & & & [1.93] & {$[1.91]$} \\
\hline Observations & 130 & 130 & 130 & 130 & 130 & 130 & 130 & 130 & 130 & 130 \\
\hline R-squared & 0.58 & 0.63 & 0.59 & 0.58 & 0,60 & 0.58 & 0.60 & 0.66 & 0.611 & 0.614 \\
\hline Number of establishments & 47 & 47 & 47 & 47 & 47 & 47 & 47 & 47 & 47 & 47 \\
\hline
\end{tabular}

Notes. 1) Coefficients are reported in the table and t-statistics in brackets.

2) Significance of the varibles is indicated as follows: * significant at 10\%; ** significant at $5 \%$; *** significant at $1 \%$

3)The t-statistics are robust to heteroscedasticity and autocorrelation within each establishment

4) The specifications include a constant, manager dummies, and year dummies

5) $R$-squared is the unadjusted within R-squared 
TABLE 5

Exogeneity Tests

\begin{tabular}{|c|c|c|c|c|c|c|c|c|}
\hline & (1) & (2) & (3) & (4) & $(5)$ & (6) & (7) & (8) \\
\hline Information sharing & $\begin{array}{c}0.077^{\star \star} \\
{[2.30]}\end{array}$ & & & & & & & \\
\hline \multirow[t]{2}{*}{ Information sharing $t+12$} & -0.004 & & & & & & & \\
\hline & {$[0.09]$} & & & & & & & \\
\hline \multirow[t]{2}{*}{ Participation on the job } & & $0.161^{\star \star \star}$ & & & & & & \\
\hline & & [3.92] & & & & & & \\
\hline \multirow[t]{2}{*}{ Participation on the job $1+12$} & & -0.002 & & & & & & \\
\hline & & {$[0.05]$} & & & & & & {$[0.24]$} \\
\hline \multirow[t]{2}{*}{ Development talks } & & & 0.052 & & & & & 0.084 \\
\hline & & & {$[0.53]$} & & & & & {$[0.91]$} \\
\hline \multirow[t]{2}{*}{ Development talks $_{1+12}$} & & & $-0.061^{\star}$ & & & & & $-0.077^{* *}$ \\
\hline & & & {$[1.81]$} & & & & & [2.28] \\
\hline \multirow[t]{2}{*}{ Performance feedback } & & & & $0.163^{\star \star \star}$ & & & & \\
\hline & & & & [3.69] & & & & \\
\hline \multirow[t]{2}{*}{ Performance feedback ${ }_{1+12}$} & & & & 0.032 & & & & \\
\hline & & & & {$[0.51]$} & & & & \\
\hline \multirow[t]{2}{*}{ Supervisor acknowledgement } & & & & & -0.002 & & & \\
\hline & & & & & {$[0,04]$} & & & \\
\hline \multirow[t]{2}{*}{ Supervisor acknowledgement ${ }_{1+12}$} & & & & & -0.016 & & & \\
\hline & & & & & [0.63] & & & \\
\hline \multirow[t]{2}{*}{ Shared goals } & & & & & & 0.035 & & \\
\hline & & & & & & [0.88] & & \\
\hline \multirow[t]{2}{*}{ Shared goals $1+12$} & & & & & & -0.012 & & \\
\hline & & & & & & {$[0.36]$} & & \\
\hline \multirow[t]{2}{*}{ Scale } & & & & & & & $0.053^{\star \star \star}$ & $0.060^{\star \star \star}$ \\
\hline & & & & & & & [3.13] & [3.17] \\
\hline \multirow[t]{2}{*}{ Scale $_{1+12}$} & & & & & & & -0.012 & -0.003 \\
\hline & & & & & & & {$[1.07]$} & \\
\hline Observations & 904 & 904 & 904 & 904 & 904 & 904 & 904 & 904 \\
\hline R-squared & 0.876 & 0.877 & 0.875 & 0.877 & 0.875 & 0.875 & 0.877 & 0.877 \\
\hline Number of establishments & 44 & 44 & 44 & 44 & 43 & 43 & 43 & 43 \\
\hline
\end{tabular}

Notes. 1) Coefficients are reported in the table and t-statistics in brackets.

2) Significance of the varibles is indicated as follows: * significant at $10 \% ; * *$ significant at $5 \%$; $* *$ significant at $1 \%$.

3)The t-statistics are robust to heteroscedasticity and autocorrelation within each establishment.

4) The specifications include a constant, manager dummies, and month and year dummies.

5) R-squared is the unadjusted within R-squared

6) Other independent variables are the same as in Table 3. 


\section{Endnotes}

${ }^{1}$ A possible exception is Banker et al. (1996) that studies the link between incentive pay and performance.

${ }^{2}$ For the specific case of Finland other work on related issues suggests that there is potentially much to be learned that is of broader interest. See for example the analysis of the effects of high performance workplace practices on Finnish workers by Kalmi and Kauhanen (2005). ${ }^{3}$ For useful reviews see Harley (2005), Appelbaum et al. (2000) and Heller et al. (1998).

${ }^{4}$ While we concentrate on Appelbaum et al, we note that others have adopted frameworks that also argue for the existence of complementarities between particular HRM practices. These frameworks also imply that different HRM environments will be expected to produce different impacts on business performance. See, for examine, Levine (1995) and Ben-Ner and Jones (1995).

${ }^{5}$ Recent years have also witnessed a growing body of research by labor economists on the retail sector that investigates other matters, for example the impact of major retailers such as Wal Mart on job creation or job destruction (Basker, 2005; Neumark et al., 2005) or links between aggregate and micro productivity (Foster et al., 2002.)

${ }^{6}$ These difficulties have also been noted by researchers in manufacturing (e.g. Cappelli and Neumark, 2001.) There is also an extensive literature that addresses similar matters for nonmainstream forms of economic organization. The review by Bonin et al (1993) includes discussion for the case of producer cooperatives.

${ }^{7}$ For a discussion on the Finnish industrial relations system see Jones et al. (2006).

${ }^{8}$ Our interviews revealed that employees may occasionally receive team-based discretionary bonuses for exceptionally good performance. However these are relatively rare and constituted only a very small fraction of total pay, and there was no formal performancerelated pay structure in the company during the study period.

${ }^{9}$ Unsurprisingly, these issues have been the subject of research in the retail marketing literature. For example, Bitner (1992) discusses the impact of the surroundings on customers (and employees), while the influence of product assortment and display is considered by Simonson (1999). Bell and Menquc (2002) and Keaveney (1995) examine the effect of interaction with customers on business performance.

${ }^{10}$ For definitions of influential observations and outliers, see e.g., Chatterjee and Hadi (1986). A closer inspection of the outliers revealed that two observations were probably contaminated by coding errors and the rest were due to exceptional demand shocks during the summertime. 
Full details of the analysis used to exclude the outliers and the 11 observations is available upon request.

${ }^{11}$ In addition we subtracted from net sales estimates for reduced prices, lost items, and value added tax (VAT).

${ }^{12}$ These particular items are selected since they correspond most closely to the theoretical concepts that we are interested in. Unfortunately the data we received do not contain good proxies for employee skills. To some extent we can control for the importance of skills by including the average tenure of employees in regressions. Note that in the Finnish context most salespeople hold a secondary degree and that, consequently, it might be inappropriate to regard "low-skill" as "unskilled".

${ }^{13}$ For a balanced panel the total variance is the sum of the within and between variances. This relation does not hold for unbalanced data. Thus calculating the share of within variance of the total variance is feasible only in the case of balanced panel.

${ }^{14}$ Becker and Huselid $(1998,63)$ argue that a coherent combination of HRM practices may depend on firm specific factors, which suggests the use of a single, additive index. MacDuffie (1995) argues that additive indexes are attractive because unlike multiplicative ones, they do not imply that if one component of the index is not present the bundle takes the value zero also. For this reason he uses additive indexes, but in the analysis he uses interaction terms of the additive indexes he constructs. Huselid (1995) uses factor analysis to identify bundles in the data, and then uses this information to construct additive scales. The additive indexes are especially attractive when the original data are based on scale variables, as opposed to binary variables.

${ }^{15}$ The stores are located in 39 different municipalities.

${ }^{16}$ Most other studies of the HR-performance link in services do not have information on these matters.

${ }^{17}$ In related literature (e.g. Bonin et al., 1993; Jones, 1987; Kruse, 1993) a recurring theme has been to empirically investigate the appropriate form of technology. Since an F-test cannot reject at the five percent level the null hypothesis of zero coefficients for the quadratic terms in the translog model, the Cobb-Douglas form is preferred over the translog. Furthermore, the Cobb-Douglas form is also preferred when applying Bayesian information criteria.

${ }^{18}$ See e.g. Cameron \& Trivedi (2005, 706-708), Wooldridge (2002, 274-278), Bertrand et al. (2004), and Kezdi (2004). 
${ }^{19}$ There have been two reasons for this. Firstly, these estimators have not been incorporated into standard econometrics packages. Secondly, their small sample properties have not been known very well. This second point is important for us, since the cross section dimension of our data is not very large.

${ }^{20}$ However, we did experiment with alternative ways of capturing the data from the survey responses, including using measures that captured dispersion in the data. Our regression findings are essentially insensitive to the use of these alternative procedures.

${ }^{21}$ The results of principal component analysis are available upon request.

${ }^{22}$ As such our approach to the creation of an index is similar to the procedure used by others such as MacDuffie (1995) and also Huselid (1995) and Huselid and Becker (1996), although the latter two studies used factor analysis.

${ }^{23}$ Precise test scores are as follows: $F(6,46)=3.03$, Prob $>F=0.014$.

${ }^{24} \mathrm{We}$ also experimented with 36 time dummies. The key results do not change. These results are available upon request.

${ }^{25}$ The F-test is as follows: $F(6,46)=5.55$; Prob $>F=0.0002$

${ }^{26}$ The results are somewhat sensitive to the choice of the lead. It is not clear how to choose the lead values in the monthly case, when the variation in the variables takes place at the annual level. Small lead values (e.g. one month lead) give different results. However, when the data are aggregated to an annual level, the choice of the lead is simpler. In the annual case, the results of these tests are similar to the 12 month lead case in the monthly data. 